\title{
CHARACTERISTICS AND PROGNOSIS OF TRIPLE-NEGATIVE BREAST CANCER PATIENTS: A CROATIAN SINGLE INSTITUTION RETROSPECTIVE COHORT STUDY
}

\author{
Ana Tečić Vuger ${ }^{1}$, Robert Šeparovići, ${ }^{1,5}$ Ljubica Vazdar ${ }^{1}$, Mirjana Pavlović ${ }^{1}$, Petra Lepetić ${ }^{1}$, \\ Sanda Šitić ${ }^{2}$ Žarko Bajićc ${ }^{3}$, Božena Šarčevićc ${ }^{4}$ and Damir Vrbanec ${ }^{5}$ \\ ${ }^{1}$ Department of Medical Oncology, Division of Radiotherapy and Medical Oncology, \\ University Hospital for Tumors, Sestre milosrdnice University Hospital Centre, Zagreb, Croatia; \\ ${ }^{2}$ Department of Oncologic Cytology and Pathology, University Hospital for Tumors, \\ Sestre milosrdnice University Hospital Centre, Zagreb, Croatia; \\ ${ }^{3}$ Dr. Mirko Grmek Scientific Unit, Sveti Ivan Psychiatric Hospital, Zagreb, Croatia; \\ ${ }^{4}$ School of Medicine, University of Zagreb, Zagreb, Croatia; \\ ${ }^{5}$ School of Medicine, Juraj Dobrila University, Pula, Croatia
}

\begin{abstract}
SUMMARY - Triple-negative breast cancer (TNBC) occurs in around one-sixth of all breast cancer $(\mathrm{BC})$ patients, with the most aggressive behavior and worst prognosis of all $\mathrm{BC}$ subtypes. It is a heterogeneous disease, with specific molecular characteristics and natural dynamics of early recurrence and fast progression. Due to the lack of biomarkers or any valid treatment targets, it can only be treated with classic cytotoxic chemotherapy. We analyzed a cohort of 152 patients, median age 58 years, diagnosed with and treated for early stage TNBC at the University Hospital for Tumors, Sestre milosrdnice University Hospital Centre, Zagreb, Croatia, during the 2009-2012 period. Patients were treated with primary surgical approach, adjuvant chemotherapy and adjuvant irradiation. We observed a relatively large proportion of locally advanced TNBC at diagnosis, with large tumor size and nodal involvement, with high grade and high proliferation index Ki67. Patient age, tumor size and lymph node involvement, as expected, were significant and clinically most important prognostic factors for 5-year disease-free survival (67\%; 95\% CI 60\%-75\%) and overall absolute survival rate (74\%; 95\% CI 66\%-81\%).
\end{abstract}

Key words: Triple negative breast cancer; Early disease; Adjuvant treatment; Tumor size; Lymph node; Disease free survival; Overall survival; Prognostic factor

\section{Introduction}

Molecular profiling has shown that breast cancer (BC) is a heterogeneous disease. According to gene expression, there are four essential, intrinsic subtypes

Correspondence to: Ana Tečić Vuger, MD, Department of Medical Oncology, Division of Radiotherapy and Medical Oncology, University Hospital for Tumors, Sestre milosrdnice University Hospital Centre, Ilica 197, HR-10000 Zagreb, Croatia

E-mail: ana.tecic@yahoo.com

Received December 30, 2019, accepted February 18, 2020 of BC: luminal A (LA), luminal B (LB), HER2 enriched, and basal-like type ${ }^{1}$. The goal of classifying $\mathrm{BC}$ is to better understand the biology and to identify biomarkers for therapeutic decision. In practice, we use immunostaining to detect three biomarkers, ER, PR and HER2, at protein level. Based on their expression, as well as expression of Ki67, we use surrogate subtypes to guide our therapeutic decision, as follows: luminal A-like, luminal B-like (HER2 positive and HER2 negative), nonluminal HER2 positive, and triple-negative BC (TNBC). These are four prognosti- 
cally different entities, diseases that behave differently, respond differently to therapy, and have different survival outcome ${ }^{2}$, with luminal subtypes, especially luminal A being the subtype with indolent disease and good outcome, and the TNBC subtype with very few therapeutic options and poor outcome ${ }^{3}$. Histologically, TNBC is in most cases invasive ductal carcinoma but may also be one of the rarer histologic subtypes such as apocrine or adenoid cystic, with better prognosis ${ }^{4}$. TNBC was first mentioned in the literature in $2005^{5}$, and since then, thousands of scientific papers have been published covering different aspects of TNBC. Since it is a highly heterogeneous disease, different subtypes of TNBC have different genetic basis, phenotypic expression, different behavior, different response to therapy and prognosis ${ }^{6}$. TNBC can be further reclassified according to gene expression, DNA and RNA changes observed, expression of proteins on tumor cell, and immune potential ${ }^{7-10}$. One of the first comprehensive molecular profilings of TNBC was Lehmann's categorization into six TNBC subtypes, as follows: basal-like 1 (BL1), basal-like 2 (BL2), mesenchymal (M), mesenchymal stem-like (MSL), luminal AR type (LAR), and immunomodulatory type (IM) ${ }^{11}$. This characterization has been further modified by Burstein and Lehmann himself into four subtypes of TNBC, i.e. two basal-like types, immunoactivated and immunosuppressed, mesenchymal and luminal androgen receptor (LAR) type ${ }^{12,13}$. In practice, TNBC and basal-like $\mathrm{BC}$ are often considered synonyms for the same entity, but based on the scientific data available, there is a substantial but not complete overlap ${ }^{14-16}$. TNBC occurs in about $12 \%-17 \%$ of BC, most commonly in younger women, often BRCA mutation carriers, or sporadically, and is characterized by aggressive nature ${ }^{17}$. Epigenetic changes are also often present in the BRCA genes of sporadically developed, nonhereditary $\mathrm{TNBC}^{18}$. TNBC are mostly poorly differentiated tumors of high mitotic index, more often involving lymph nodes and lymphovascular spaces, and growing faster. Due to these aggressive characteristics, they are more sensitive to chemotherapy and evidently respond better compared to other BC subtypes ${ }^{3,19-21}$. However, despite better initial responses to therapy reported, the end outcomes in treating TNBC are much worse than in other $\mathrm{BC}$ subtypes, a phenomenon known as the "TNBC paradox"22.TNBC is characterized by aggressive behavior including high metastatic potential, higher rates of local and distant disease re- currence, a particular tendency to deliver distant, visceral metastases, most commonly to the lungs and brain, rapid progression and short time from the appearance of distant metastases to death ${ }^{19,20}$. The described dynamics of TNBC has been observed within the first 3 to 5 years of the diagnosis, after which the risk of disease recurrence and the rate of return and dissemination of disease are equated with those observed in other BC subtypes, which have a lower and more uniform risk of disease recurrence over a longer period of time ${ }^{23}$. There is no effect of endocrine therapy or targeted anti-HER2 therapy in TNBC. The backbone of TNBC treatment is still classic cytotoxic therapy. The optimal chemotherapy approach to TNBC has not been defined and the treatment principles used in other types of $\mathrm{BC}$ are also used in TNBC, with the fact that TNBC is much more likely to have more risk factors present that influence therapeutic decision ${ }^{24}$. TNBC shows high rates of pathologic complete response ( $\mathrm{pCR}$ ) to neoadjuvant chemotherapy (NAT), and when pCR is achieved, the long-term overall survival (OS) is often good. However, in cases where $\mathrm{pCR}$ is not achieved, the prognosis of TNBC is very poor and significantly worse than in other types of $\mathrm{BC}^{21,25}$. In systemic approach, chemotherapy based on anthracyclines and taxanes is most commonly used ${ }^{26,27}$, and the use of other drugs such as platinum compounds has been shown to be effective, especially in the treatment of BRCA mutated $\mathrm{TNBC}^{26,28}$. Capecitabine is also often used as adjuvant treatment, if NAT failed to provide $\mathrm{pCR}^{29}$. In addition to conventional cytotoxic therapy, some targeted therapies have also been attempted, and poly(ADP-ribose) polymerase (PARP) inhibitors are showing very encouraging results in metastatic setting ${ }^{30-33}$. A certain proportion of TNBC express androgen receptors, which are an attractive therapeutic target ${ }^{34}$. In recent years, there has been a growing interest in the immunogenicity of TNBC and immunotherapy as a new, potentially successful therapeutic approach. Data in the metastatic setting are strongly proposing survival impact ${ }^{35}$, and the lately results of neoadjuvant experience also direct the interest towards the immunologic arsenal ${ }^{36}$.

The primary objective of our study was to identify the prognostic factors associated with TNBC outcome. Secondary objectives were to describe the characteristics of TNBC, its treatment and treatment outcomes in real-world clinical practice, based on a single institution experience. 


\section{Patients and Methods}

\section{Study design}

We conducted this observational, real-world, single-center, retrospective cohort study at the University Hospital for Tumors, Sestre milosrdnice University Hospital Centre, Zagreb, Croatia, with 5-year followup, on a consecutive sample of all women diagnosed with and treated for early TNBC from January 1,2009 to December 31, 2012. The study protocol was approved by the Ethics Committee of the Sestre milosrdnice University Hospital Centre and Ethics Committee of the School of Medicine, University of Zagreb. The study was conducted in accordance with all applicable guidelines and rules, including the World Health Organization Helsinki Declaration of 1975, as amended in $2013^{29,37}$, the Health Care Act of the Republic of Croatia and the Patient Rights Act of the Republic of Croatia. The identity of patients was only known to the principal investigator, and identity data were not collected or recorded.

\section{Target population}

The target population included patients diagnosed with early TNBC. The diagnosis of TNBC was made by analysis of tumor tissue specimens treated with a standard histopathologic method involving tissue fixation in $10 \%$ buffered formalin and paraffin embedding (FFPE specimens), with an immunohistochemically proven negative reaction to ER/PR and HER2 status. Patients whose samples were in accordance with the current American Society of Clinical Oncology/College of American Pathologists (ASCO/CAP) recommendations for HR and HER2 testing were included in the analysis ${ }^{27,28,38,39}$. The triple negative tumor was therefore defined by ER/PR $<1 \%$ and negative HER2 (immunohistochemistry (IHC) 0 and $1+$ and IHC 2+ but in situ hybridization (ISH) negative). Inclusion criteria were age $\geq 18$ years, patient diagnosed with early TNBC without other malignancies (excluding basal cell skin cancer), histopathologic confirmation of TNBC, and clinical and radiological confirmation of early stage disease. Exclusion criteria were diagnosis of other malignant tumor, BC recurrence, advanced (metastatic) disease, bilateral $\mathrm{BC}$ regardless of the disease biology, multiple $\mathrm{BC}$ if the focal points of the tumor had proven different biology, and male sex.

\section{Sample type and sample size required}

The minimum sample size required was calculated before data collection for the primary objective with the following assumptions: statistical significance level $\mathrm{p}<0.05$, targeted statistical power of $80 \%$, eight prognostic factors (age, menopausal status, comorbidities, histologic type, tumor size, number of positive lymph nodes and grade, all measured at the time of diagnosis), and minimum partial coefficient of determination considered clinically relevant $R^{2} \geq 0.10$. Under these assumptions, a sample size of 144 patients was finally required. Given the retrospective nature of the study, we expected that $\leq 15 \%$ of patients would have missing data on the primary outcome and at least one of the eight prognostic factors. Therefore, we decided to increase the number of enrolled patients to 170 .

\section{Outcomes}

The primary outcome was the 5-year absolute survival rate defined as the percentage of patients who were alive after 5 years of primary surgery. The first secondary outcome was the OS defined as the time in months from primary surgery to death from any cause. OS data on patients who were alive after five years were censored at the time of their last visit. The second secondary outcome was the 5-year disease-free survival (DFS) rate defined as the percentage of patients with no disease recurrence or death after 5 years of primary surgery. The third secondary outcome was DFS defined as the time in months without any signs or symptoms of TNBC from surgery to disease recurrence or death from any cause. DFS data on patients with no disease recurrence were censored at the time of their last visit.

\section{Prognostic factors}

We defined prognostic factors as the tumor and $\mathrm{pa}^{-}$ tient characteristics the value of which at the time of diagnosis was associated with the natural course of TNBC or outcome of the standard treatment. Clinical, sociodemographic and histopathologic possible prognostic factors that we assessed for our primary objective were age in years, menopausal status confirmed by physician, presence of any comorbidity recorded in the hospital electronic medical records, tumor histologic type dichotomized into ductal carcinoma or other, tumor size measured in millimeters, number of 
positive lymph nodes, histologic tumor grade, and proliferative index Ki67.

\section{Other descriptive variables}

Additional variables we used to describe the characteristics of TNBC and standard treatment were selfreported family history, surgical treatment applied, lymph node dissection, adjuvant systemic treatment, type of chemotherapy administered, and adjuvant irradiation.

\section{Statistical analysis}

We performed primary analysis of the 5-year absolute survival rate using the multivariable binary logistic regression with all eight possible prognostic factors entered simultaneously. In the introductory series of bivariable binary logistic regressions, we analyzed menopausal status as well, but we excluded it from the main analysis to prevent the multicollinearity with age. We repeated primary analysis with age excluded and menopausal status included. In presentation of the logistic regression results, we presented odds ratios $(\mathrm{OR})$ with their $95 \%$ confidence intervals $(\mathrm{CI})$, statistical significance, and the false discovery rate (FDR). We described secondary outcomes, OS and DFS using Kaplan-Meier curves with $95 \%$ CI. Data on comorbidities were missing in six (3.9\%) patients. For multivariable analyses we imputed the missing data using multiple imputation with Markov Chain Monte Carlo procedures, data augmentation algorithm. We set the seed at 374823 to enable replication of multiple imputations and did 20 imputations using all possible prognostic factors as predictors. Due to the large number of missing data, we did not use positive family history for any cancer and for BC, and body mass index. We controlled the false positive finding rate using the Benjamini-Hochberg procedure with FDR $<10 \%$. We set the level of two-tailed statistical significance at $\mathrm{p}<0.05$ and all CI at $95 \%$. Statistical analysis was performed using the StataCorp. 2019 Stata Statistical Software: Release 16 (StataCorp LLC, College Station, TX, USA).

\section{Results}

\section{Sociodemographic and clinical characteristics of TNBC patients}

We enrolled 152 patients aged 26-85, median (IQR) age 58 (47-70) years (Table 1), just over two-
Table 1. Patient characteristics at diagnosis $(N=152)$

\begin{tabular}{|l|l|l|}
\hline & $\mathrm{n}$ & $(\%)$ \\
\hline Age (years), median (IQR) & 58 & $(47-70)$ \\
\hline Menopause & 98 & $(64.5)$ \\
\hline Comorbidities* & 89 & $(61.0)$ \\
\hline Cancer in family $\dagger$ & 39 & $(35.5)$ \\
\hline Breast cancer in family $\dagger$ & 18 & $(16.5)$ \\
\hline Histopathology: & & \\
Ductal carcinoma (NOS) & 128 & $(84.2)$ \\
Lobular carcinoma & 1 & $(0.7)$ \\
Medullary carcinoma & 14 & $(9.21)$ \\
Apocrine carcinoma & 4 & $(2.63)$ \\
Other & 5 & $(3.29)$ \\
\hline Tumor size (cm), median (IQR) & 2.2 & $(1.55-2.95)$ \\
T1 & 57 & $(37.5)$ \\
T2 & 83 & $(54.6)$ \\
T3 & 12 & $(7.9)$ \\
\hline Lymph nodes & & \\
N0 & 90 & $(59.2)$ \\
N1 & 35 & $(23.0)$ \\
N2 & 12 & $(7.9)$ \\
N3 & 15 & $(9.9)$ \\
\hline Lymph nodes examined, median & 16 & $(12-20)$ \\
(IQR) & 62 & $(40.8)$ \\
\hline Lymph nodes positive & & \\
\hline Grade & 3 & $(2.0)$ \\
I & 25 & $(16.5)$ \\
II & 124 & $(81.6)$ \\
III & 57 & $(29-77)$ \\
\hline Ki-67, median (IQR) & 23 & $(15.1)$ \\
Ki67 <20 & 129 & $(84.9)$ \\
Ki67 $\geq 20$ & & \\
\hline & & \\
\hline
\end{tabular}

Data are presented as number (percentage) of patients, if not specified otherwise; IQR = interquartile range; NOS = not otherwise specified; *data were missing for comorbidities in 6 (3.9\%) patients; †due to too much data missing, family history was not included in analysis: cancer in family $42(27.6 \%)$ data missing, breast cancer in family 43 (28.3\%) data missing.

thirds of them menopausal. In routine medical records, family history data were lacking in a high percentage of cases, i.e. $42(27.6 \%)$ for any cancer and $43(28.3 \%)$ for BC. We kept these data in descriptive Table 1, but did not interpret them. In patients for whom we had properly collected data, 18/109 (16.5\%) had a positive 
Table 2. Treatment approach $(N=152)$

\begin{tabular}{|l|l|l|}
\hline & $\mathrm{n}$ & $(\%)$ \\
\hline Type of surgery: & & \\
Conservative & 93 & $(61.2)$ \\
Radical & 59 & $(38.8)$ \\
\hline Axillary dissection & 150 & $(98.7)$ \\
\hline Adjuvant chemotherapy & 131 & $(88.5)$ \\
\hline Type of chemotherapy: & & \\
Anthracyclines & 71 & $(55.5)$ \\
Anthracyclines and taxanes & 43 & $(33.6)$ \\
CMF & 11 & $(8.6)$ \\
Taxanes only & 1 & $(0.8)$ \\
Other & 2 & $(1.6)$ \\
\hline Adjuvant radiotherapy & 103 & $(73.6)$ \\
\hline
\end{tabular}

$\mathrm{CMF}$ = cyclophosphamide-methotrexate-5-fluorouracil; data were missing for adjuvant chemotherapy in 4 (2.6\%) and type of chemotherapy in $3(2.3 \%)$ out of 131 patients treated with adjuvant chemotherapy; and for adjuvant radiotherapy in 12 (7.9\%) patients.

family history of BC. Patients with a positive family history of $\mathrm{BC}$ were younger, median (IQR) age 43 (38-54) years compared to patients without family $\mathrm{BC}$, median (IQR) age 57 (47-69) years. The vast majority of patients had ductal invasive carcinoma with a median (IQR) tumor size of $2.2(1.55-2.95) \mathrm{cm}, 62$
(40.8\%) with positive lymph nodes, 124 (81.6\%) with grade III tumor, and median (IQR) Ki67 proliferation index 57 (29-77). Just over one-third of patients underwent radical surgery (Table 2), and almost all of them underwent axillary dissection. Adjuvant chemotherapy was used in $130 / 148(87.8 \%)$ patients, in $114 / 128(89.1 \%)$ cases with anthracyclines or a combination of anthracyclines and taxanes. A total of 103/140 (73.6\%) patients were treated with adjuvant radiotherapy. None of the patients was treated with the neoadjuvant approach.

\section{Treatment outcomes}

During the 5-year follow-up from BC surgery, 50/151 (32.9\%; 95\% CI 25.5-41.0\%) patients experienced disease recurrence or death, and 40/152 (26.3\%; 95\% CI 19.5-34.1\%) died. Thus, the overall 5-year absolute survival rate was 112/152 (73.7\%; 95\% CI 65.980.5\%). At the last examination, 102/152 (67.1\%; 95\% CI 59.6-74.7\%) patients were alive and with no disease, so the median DFS was not reached during the 5 -year follow-up (Fig. 1). The lower quartile $\left(25^{\text {th }}\right.$ percentile) of DFS was 60 months. The arithmetic mean of DFS was 48 (95\% CI 45-51) months. Median (IQR) OS was not reached at five-year follow-up (Fig. 2). The lower quartile ( $25^{\text {th }}$ percentile) of OS was 54

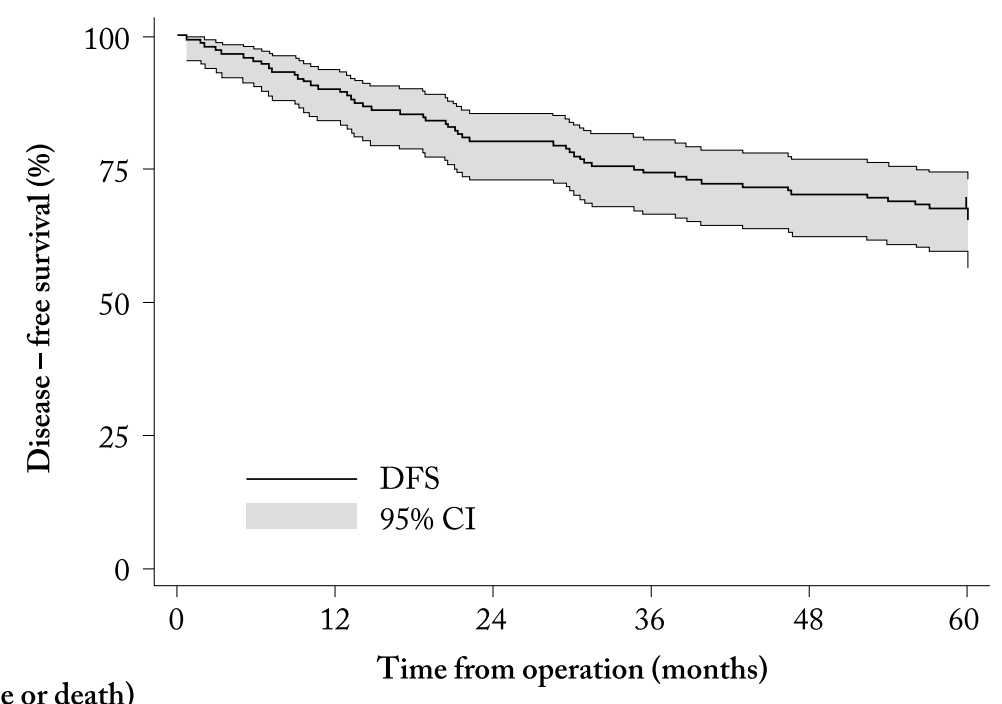

Number at risk (relapse or death)
152
(15) 137
(15) 122
(9) 113
(6) 107
(4) 73

Fig. 1. Kaplan-Meier curve of survival without disease recurrence or death in months from surgery $(N=152)$.

DFS = disease free survival; $\mathrm{CI}=$ confidence interval 


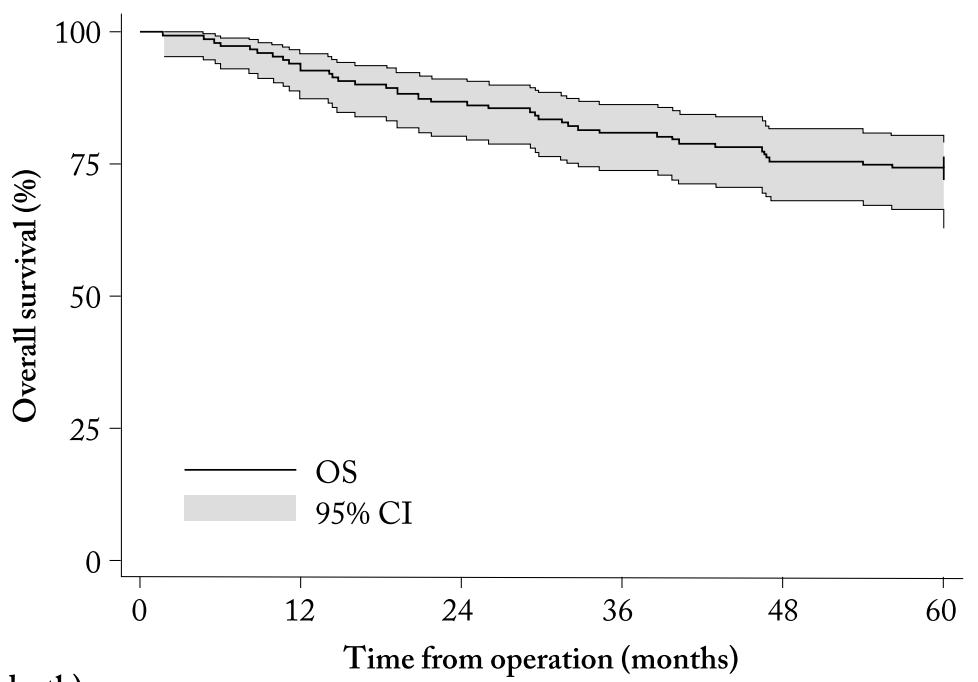

Number at risk (death)

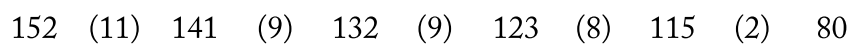

Fig. 2. Kaplan-Meier survival curve in months from surgery $(N=152)$.

$\mathrm{OS}=$ overall survival; $\mathrm{CI}=$ confidence interval

months. The arithmetic mean of OS was 51 (95\% CI 48-54) months.

\section{Prognostic factors}

After adjustment for all other possible prognostic factors using the multivariable binary logistic regression, the absolute 5 -year survival rate was significantly associated with age (OR=0.95; 95\% CI 0.92-0.99; $\mathrm{p}=0.007$; FDR $<10 \%$ ), tumor size (OR=0.65; 95\% CI 0.48-0.88; $\mathrm{p}=0.006$; FDR $<10 \%)$, and number of positive lymph nodes (OR=0.78; 95\% CI 0.67-0.90; $\mathrm{p}=0.001 ;$ FDR $<10 \%$ ) (Table 3). Older age, larger tumor size and more positive axillary lymph nodes were associated with worse prognosis. In repeated multivariable analysis with age excluded and menopausal status included, menopausal status was not the independent significant prognostic factor for the absolute 5-year survival rate $(\mathrm{OR}=0.74 ; 95 \%$ CI $0.27-2.02 ; \mathrm{p}=0.552$; FDR $>10 \%)$.

\section{Discussion}

This paper presents the retrospective cohort study in 152 patients diagnosed with and treated for early TNBC. We observed the significant and clinically relevant prognostic value of age, tumor size and number of positive lymph nodes measured at the time of diagnosis for the 5-year absolute survival rate.
With a median age of 58 years, this cohort of patients was comparable to the cohorts in several similar studies in patients with early TNBC conducted in recent years in the relatively close geographical areas (Slovenia, Italy), but also in other parts of the world (Canada) ${ }^{23,40-42}$. Patients younger by ten years were studied in India, Kuwait and Turkey ${ }^{43-45}$, which is in line with the well-documented fact that patients with TNBC from these countries are mostly younger compared to other geographical areas. Accordingly, it is not surprising that $64 \%$ of patients in our cohort were postmenopausal, compared to a similar population of patients younger by three years in Slovenian study ${ }^{40}$ and Italian ${ }^{42}$ studies with $60 \%$ of postmenopausal patients. Despite the large proportion of family predisposition data, a positive family history of $\mathrm{BC}$ was observed in about one-sixth of the patients analyzed, and these patients were by even 15 years younger than those without a positive family history were, which is in line with the data expected for a population of patients with hereditary predisposition for $\mathrm{BC}^{46}$. Unfortunately, at the time the designated cohort of patients was treated, there was no recommendation for BRCA testing to be conducted, according to risk, as encouraged today, yet not routinely performed, or reflex testing in all TNBC patients in our country. As expected, the most prevalent histologic subtype of TNBC was 
Table 3. Association of 5-year absolute survival rate with sociodemographic and clinical characteristics of patients $(N=152)$

\begin{tabular}{|c|c|c|c|c|c|c|c|c|}
\hline & \multicolumn{2}{|c|}{ Survived } & \multicolumn{3}{|c|}{ Bivariable, unadjusted analysis } & \multicolumn{3}{|c|}{ Multivariable, adjusted analysis } \\
\hline & $\mathrm{n}$ & $(\%)$ & OR & $(95 \% \mathrm{CI})$ & $\mathrm{p}$ & OR & $(95 \% \mathrm{CI})$ & $\mathrm{p}$ \\
\hline Age (years) & n.a. & & 0.96 & $(0.94-0.99)$ & 0.005 & 0.95 & $(0.92-0.99)$ & 0.007 \\
\hline \multicolumn{9}{|l|}{ Menopause*: } \\
\hline No & 43 & $(79.6)$ & 1 & & & & & \\
\hline Yes & 69 & $(70.4)$ & 0.61 & $(0.28-1.34)$ & 0.219 & & & \\
\hline \multicolumn{9}{|l|}{ Comorbidities $\dagger:$} \\
\hline No & 45 & $(71.4)$ & 1 & & & 1 & & \\
\hline Yes & 67 & $(75.3)$ & 1.22 & $(0.59-2.52)$ & 0.595 & 1.68 & $(0.60-4.73)$ & 0.323 \\
\hline \multicolumn{9}{|l|}{ Histopathology: } \\
\hline Other & 19 & $(79.2)$ & 1 & & & 1 & & \\
\hline Ductal carcinoma (NOS) & 93 & $(72.7)$ & 0.70 & $(0.24-202)$ & 0.508 & 0.76 & $(0.22-2.57)$ & 0.657 \\
\hline Tumor size & n.a. & & 0.69 & $(0.54-0.88)$ & 0.003 & 0.65 & $(0.48-0.88)$ & 0.006 \\
\hline Number of positive lymph nodes & n.a. & & 0.75 & $(0.65-0.85)$ & $<0.001$ & 0.78 & $(0.67-0.90)$ & 0.001 \\
\hline \multicolumn{9}{|l|}{ Grade } \\
\hline I-II & 20 & $(71.4)$ & 1 & & & 1 & & \\
\hline III & 92 & $(74.2)$ & 1.15 & $(0.46-2.87)$ & 0.764 & 0.74 & $(0.26-2.11)$ & 0.579 \\
\hline Ki67 & n.a. & & 1.01 & $(1.00-1.02)$ & 0.154 & 1.02 & $(1.00-1.04)$ & 0.083 \\
\hline \multicolumn{9}{|l|}{ Type of surgery: } \\
\hline Conservative & 81 & $(87.1)$ & 1 & & & & & \\
\hline Radical & 31 & $(52.5)$ & 0.16 & $(0.07-0.36)$ & $<0.001$ & & & \\
\hline \multicolumn{9}{|l|}{ Adjuvant chemotherapy: } \\
\hline None & 13 & $(54.2)$ & 1 & & & & & \\
\hline Other & 5 & $(35.7)$ & 0.47 & $(0.12-1.82)$ & 0.275 & & & \\
\hline Anthracyclines & 63 & $(88.7)$ & 6.66 & $(2.24-19.80)$ & 0.001 & & & \\
\hline Anthracyclines and taxanes & 31 & $(72.1)$ & 2.19 & $(0.77-6.21)$ & 0.142 & & & \\
\hline
\end{tabular}

n.a. = not available; $\mathrm{n}=$ number of patients; $\mathrm{OR}=$ odds ratio; $\mathrm{CI}=$ confidence interval; $\mathrm{p}=$ statistical significance calculated using binary logistic regression; NOS = not otherwise specified; *data were missing for 6 (3.9\%) patients and were imputed using multiple imputation; tmenopausal status was excluded from multivariable analysis to prevent multicollinearity with age.

ductal invasive carcinoma, while the prevalence of medullary cancer, which, although one of the rare special histologic subtypes of $\mathrm{BC}$, is expected to be highest among TNBC, is also noticeable ${ }^{4}$. A similar distribution was observed in other comparable studies ${ }^{40-42}$.

In our cohort, the definition of TNBC implied, in addition to the negative finding of HER2 (either IHC or ISH), IHC negative ER and PR according to the valid ASCO/CAP recommendations, which was $<1 \%$ of expression ${ }^{38}$. The same pattern was used in several recent comparative analyses ${ }^{42}$, and differed somewhat from similar analyses in which a limit value of IHC was taken to have an ER/PR expression of $10 \%$ and therefore so-called borderline tumors (1\%-9\% IHC ER/PR) were analyzed as $\mathrm{TNBC}^{23,40,41,47}$. The above should be taken into account when interpreting the results obtained, as a possible explanation for the observed differences in the cohorts compared ${ }^{38,48}$. As in similar analyses ${ }^{49}$, our patients with early TNBC most often had a tumor larger than $2 \mathrm{~cm}$ and more than $40 \%$ of them had positive lymph nodes already at diagnosis, which agrees with the known facts about TNBC as the most aggressive and rapidly progressing tumor, which gives metastases to the lymph nodes very early and with small primary tumors ${ }^{20-22,50}$. This was relativized in a study by US authors who showed the 
least correlation of the triple-negative phenotype with positive lymph nodes; however, this phenomenon is not clearly explained ${ }^{51}$.

More than one-fifth of our patients had N2 or N3 stage lymph nodes. These are, by definition, initially borderline or clearly inoperable diseases, that is, they describe the locally advanced disease stage (LABC) and imply the need for primary systemic treatment (neoadjuvant approach) ${ }^{52,53}$. The fact that patients in this cohort, from 2009 to 2012, were treated exclusively with primary surgery and then with adjuvant systemic therapy and radiation, without applying a neoadjuvant approach despite the diagnosis of LABC, indicates the evolution of patient care from treatment times of this cohort to date, when they are known to have a clear indication for neoadjuvant treatment ${ }^{53,54}$. Patients in our cohort, as expected, and similarly observed in other concordant analyses ${ }^{40-43,49}$, had a high tumor grade and significantly high Ki67 proliferation index, which also confirms the more aggressive nature of TNBC compared to other BC subtypes. As mentioned above, patients, unlike today's treatment approach, with a higher proportion of neoadjuvant access were treated exclusively with breast surgery, axillary dissection in almost all of them, and then adjuvant chemotherapy and radiotherapy. In contrast to over $80 \%$ of mastectomies reported in the Chinese analysis $^{48}$, in this cohort of patients, conservative surgery was performed in more than $60 \%$ of cases, although not followed accordingly with sentinel lymph node biopsy for axillary staging and also possible definitive treatment, according to today's standard practice in low risk $\operatorname{cases}^{54}$, but rather with axillary dissection in almost all cases. Although in some comparable analyses, the percentage of conservative surgery was similar to ours ${ }^{43}$, there was a marked difference between $\mathrm{co}^{-}$ horts according to disease stage at diagnosis (significantly more LABC in our cohort, possibly also due to implementation of the national screening program just shortly before the designated cohort of patients was treated, meaning having only first cycle of mammography screening program passed, before this population of patients), thus justifying the conservative approach in those cohorts. Considering the previously mentioned fact of not using the neoadjuvant treatment approach, and the significant number of LABCs at diagnosis in our cohort of patients, this is certainly not a reflection of criticality, from today's perspective, how- ever, it is a reflection of the standard of care in the analyzed period. Chemotherapy was most often based on anthracyclines and taxanes, which to this day remain the standard choice for the systemic treatment of more aggressive BC subtypes ${ }^{54,55}$.

The overall absolute 5-year survival rate in our study was strikingly similar to the one observed in the Slovenian ${ }^{41}$ and Italian ${ }^{43}$ studies, markedly lower than in the Chinese one ${ }^{48}$, where $89 \%$ of patients were alive after five years, and markedly better than the Indian cohort analyzed during the similar period, with a reported 3-year OS of $66 \%{ }^{44}$. Similar survival results in our cohort to those reported by Slovenian and Italian authors can also partially be interpreted by similar characteristics of patients living in the close geographical area, and by the similar treatments used, i.e. similar use of operative treatment, radiation and chemotherapy. Likewise, the reason for better OS compared to the Chinese study may also be partially interpreted by the fact that these patients had less advanced disease (stages I and II >70\%) and more radical treatment (mastectomy $>80 \%$ ). The Indian cohort of patients observed during the same period as ours had a larger primary tumor in a larger number of patients ( $89 \%$ of patients with tumor $>2 \mathrm{~cm}$ ) and almost $60 \%$ of cases of positive lymph nodes. Patients in our cohort experienced disease recurrence or death similar to the Slovenian (32\%) and Italian (33\% after 4.3-year follow-up) cohorts of patients $^{40,42}$.

As expected, the most significant prognostic factors were age, tumor size, and positive lymph nodes $^{53,55,56}$. As in the other studies mentioned, the higher the tumor size and the more lymph nodes affected, indicating a more advanced stage of the disease, the worse is the prognosis ${ }^{40-45,47}$. In contrast to our results, where younger patients had higher odds for disease recurrence and death, which is consistent with the known facts about greater aggression of the disease at a younger age and probably different essential biology than the disease in the older population, in the Slovenian study older patients had a higher risk, which is also explained by the fact that a much smaller percentage of older patients are treated with adjuvant chemotherapy ${ }^{40}$. The Ki67 proliferation index proportionally increased the risk of disease recurrence and death, once again indirectly pointing to the described TNBC par$\operatorname{adox}^{23}$, where more aggressive tumors with a significant degree of high cell proliferation are expected to be 
more chemosensitive; however, because of its marked and large percentage of local and especially distant disease recurrences have worse survival rates.

\section{Limitations of the study}

The first limitation of our description of TNBC characteristics was its possible lower generalizability (external validity) caused by the fact, as already explained, that at the time of observation neoadjuvant chemotherapy was not a standard procedure in our institution. It is likely that the absolute 5-year survival rates in the currently treated patients are better than the ones we observed. As the neoadjuvant chemotherapy may have affected both the tumor size and the primary and adjuvant treatment outcomes, it is possible that the role of this and other prognostic factors would be different after the neoadjuvant treatment. It was not possible to estimate the extent of this lowering of external validity. Another threat to the generalizability was probably caused by the fact that we observed the cohort diagnosed and treated in a single center. It is not impossible that the standard treatment and/or even patient characteristics, and consequently treatment outcomes differ between our and other centers. Moreover, as the participating institution is a highly specialized department in country capital, it is possible that our catchment population is different from the populations in smaller, provincial hospitals, for example, if the detection rate is better in the wealthier, better-educated and more urbanized country capital. Furthermore, this opened our study to the selection and referral biases as well. The second limitation was inherent to the retrospective cohort design with the hospital medical records as the main data source, i.e. a large proportion of missing data on some potentially important prognostic factors, which prevented us from analyzing them. If we were able to include, for example, body mass index, it may be that some of the presented results of the multivariable, adjusted analysis would be different. The third limitation was the absence of a comparator, thus some of our findings may not be TNBC specific. Although the real setting, together with a proper statistical power and long-enough follow-up, was probably the main strong point of our study, at the same time the absence of patient randomization to different therapeutic regimens might have resulted in lower internal validity of our findings on the importance of particular prognostic factors, par- ticularly those that are highly associated with treatment decisions. It is just not possible to reliably differentiate prognostic from the predictive role of any factor without the randomized controlled design.

\section{Conclusions}

In this analysis of early TNBC patient cohort, we observed a relatively large proportion of locally advanced TNBC at diagnosis, with large tumor size and nodal involvement, high grade and high Ki67. Patient age, tumor size and lymph node involvement, as expected, were significant and clinically most important prognostic factors for 5-year DFS and OS. Observed characteristics of patients with early TNBC in this cohort were mostly expected and reported in similar studies, which in global reminds of the need for early detection and further encourages national $\mathrm{BC}$ screening programs. The observation that, although in a great percentage locally advanced cancer, there was no neoadjuvant approach conducted in this cohort, points to the fact that there has been a clear shift from that time to the present, from the adjuvant to neoadjuvant approach in TNBC, following the enlargement of robustness of data to the benefits of primary systemic treatment in TNBC. The expected poorer survival of patients with TNBC, taking into account all those factors, from clinical, sociodemographic and histopathologic to therapeutic, reaffirms the previously noted need to further search for a solution for this group of patients, beyond current therapeutic standards in terms of adjustment for surgical treatment and choice of chemotherapy. One of the most promising ways is the search for new therapeutic targets, and some newly diagnosed biomarkers within TNBC will definitely open arena for new treatment options.

\section{References}

1. Sorlie T, Perou CM, Tibshirani R, Aas T, Geisler S, Johnsen H, et al. Gene expression patterns of breast carcinomas distinguish tumor subclasses with clinical implications. Proc Natl Acad Sci. 2001 Sep 11;98(19):10869-74. doi: 10.1073/pnas.191367098.

2. Vasconcelos I, Hussainzada A, Berger S, Fietze E, Linke J, Siedentopf $\mathrm{F}$, et al. The $\mathrm{St}$. Gallen surrogate classification for breast cancer subtypes successfully predicts tumor presenting features, nodal involvement, recurrence patterns and disease free survival. Breast. 2016 Oct;29:181-5. doi: 10.1016/j.breast.2016. 07.016 . 
3. Hudis CA, Gianni L. Triple-negative breast cancer: an unmet medical need. Oncologist. 2011 Jan 1;16(Suppl 1):1-11. doi: 10.1634/theoncologist.2011-S1-01.

4. Mills MN, Yang GQ, Oliver DE, Liveringhouse CL, Ahmed KA, Orman AG, et al. Histologic heterogeneity of triple negative breast cancer: a National Cancer Centre Database analysis. Eur J Cancer. 2018 Jul;98:48-58. doi: 10.1016/j.ejca.2018. 04.011.

5. Brenton JD, Carey LA, Ahmed AA, Caldas C. Molecular classification and molecular forecasting of breast cancer: ready for clinical application? J Clin Oncol. 2005 Oct 10;23(29):735060. doi: 10.1200/JCO.2005.03.3845.

6. Bareche Y, Venet D, Ignatiadis M, Aftimos P, Piccart M, Rothe $\mathrm{F}$, et al. Unravelling triple-negative breast cancer molecular heterogeneity using an integrative multiomic analysis. Ann Oncol. 2018 Apr 1;29(4):895-902. doi: 10.1093/annonc/mdy024.

7. Lehmann BD, Pietenpol JA, Tan AR. Triple-negative breast cancer: molecular subtypes and new targets for therapy. Am Soc Clin Oncol Educ B. 2015;35:e31-9. doi: 10.14694/EdBook_AM.2015.35.e31.

8. Yadav BS. Biomarkers in triple negative breast cancer: a review. World J Clin Oncol. 2015;6(6):252. doi: 10.5306/wjco.v6. i6.252.

9. Millis SZ, Gatalica Z, Winkler J, Vranic S, Kimbrough J, Reddy S, et al. Predictive biomarker profiling of $>6000$ breast cancer patients show heterogeneity in TNBC, with treatment implications. Clin Breast Cancer. 2015 Dec;15(6):473-81.e3. doi: 10.1016/j.clbc.2015.04.008.

10. Uscanga-Perales GI, Santuario-Facio SK, Ortiz-López R. Triple negative breast cancer: deciphering the biology and heterogeneity. Med Univ. 2016 Apr;18(71):105-14. doi:10.1016/j. rmu.2016.05.007.

11. Lehmann BD, Bauer JA, Chen X, Sanders ME, Chakravarthy AB, Shyr Y, Pietenpol JA. Identification of human triple-negative breast cancer subtypes and preclinical models for selection of targeted therapies. J Clin Invest. 2011;121(7):2750-67. doi: 10.1172/JCI45014.

12. Burstein MD, Tsimelzon A, Poage GM, et al. Comprehensive genomic analysis identifies novel subtypes and targets of triplenegative breast cancer. Clin Cancer Res. 2015;21(7):1688-98. doi: 10.1158/1078-0432.CCR-14-0432.

13. Lehmann BD, Jovanović B, Chen X,Estrada MV, Johnson KN, Shyr $\mathrm{Y}$, et al. Refinement of triple-negative breast cancer molecular subtypes: implications for neoadjuvant chemotherapy selection. PLoS One. 2016 Jun 16;11(6):e0157368. doi: 10.1371/journal.pone.0157368.

14. Carey L, Winer E, Viale G, Cameron D, Gianni L. Triplenegative breast cancer: disease entity or title of convenience? Nat Rev Clin Oncol. 2010 Dec 28;7(12):683-92. doi: 10.1038/ nrclinonc.2010.154.

15. Foulkes WD, Smith IE, Reis-Filho JS. Triple-negative breast cancer. N Engl J Med. 2010 Nov 11;363(20):1938-48. doi: 10.1056/NEJMra1001389.

16. Prat A, Adamo B, Cheang MC, Anders CK, Carey LA, Perou $\mathrm{CM}$. Molecular characterization of basal-like and non-basal- like triple-negative breast cancer. Oncologist. 2013;18(2):12333. doi: 10.1634/theoncologist.2012-0397.

17. Trivers KF, Lund MJ, Porter PL, Liff JM, Flagg EW, Coates RJ, Eley JW. The epidemiology of triple-negative breast cancer, including race. Cancer Causes Control. 2009;20:1071-82. doi: 10.1007/s10552-009-9331-1.

18. Temian DC, Pop LA, Irimie AI, Berindan-Neagoe I. The epigenetics of triple-negative and basal-like breast cancer: current knowledge. J Breast Cancer. 2018;21(3):233-43. doi: 10.4048/ jbc.2018.21.e41

19. Anders CK, Carey LA. Biology, metastatic patterns, and treatment of patients with triple-negative breast cancer. Clin Breast Cancer. 2009 Jun;9:S73-81. doi: 10.3816/CBC.2009.s.008.

20. Jitariu A-A, Cîmpean AM, Ribatti D, Raica M. Triple negative breast cancer: the kiss of death. Oncotarget. 2017 Jul 11;8:28. doi: 10.18632/oncotarget.16938.

21. Liedtke C, Mazouni C, Hess KR, André F, Tordai A, Mejia JA, et al. Response to neoadjuvant therapy and long-term survival in patients with triple-negative breast cancer. J Clin Oncol. 2008 Mar 10;26(8):1275-81. doi: 10.1200/JCO.2007.14.4147.

22. Carey LA, Dees EC, Sawyer L, Gatti L, Moore DT, Collichio F, et al. The triple negative paradox: primary tumor chemosensitivity of breast cancer subtypes. Clin Cancer Res. 2007 Apr 15;13(8):2329-34. doi: 10.1158/1078-0432.CCR-06-1109.

23. Dent R, Trudeau M, Pritchard KI, Hanna WM, Kahn HK, Sawka CA, et al. Triple-negative breast cancer: clinical features and patterns of recurrence. Clin Cancer Res. 2007 Aug 1;13 (15):4429-34. doi: 10.1158/1078-0432.CCR-06-3045.

24. Gadi VK, Davidson NE. Practical approach to triple-negative breast cancer. J Oncol Pract. 2017 May;13(5):293-300. doi: 10.1200/JOP.2017.022632.

25. Amos KD, Adamo B, Anders CK. Triple-negative breast cancer: an update on neoadjuvant clinical trials. Int J Breast Cancer. 2012;2012:1-7. doi: 10.1155/2012/385978.

26. Isakoff SJ. Triple-negative breast cancer. Cancer J. 2010 Jan; 16(1):53-61. doi: 10.1097/PPO.0b013e3181d24ff7.

27. Mustacchi G, De Laurentiis M. The role of taxanes in triplenegative breast cancer: literature review. Drug Des Devel Ther. 2015 Aug;4303. doi: 10.2147/DDDT.S86105.

28. Curigliano G. Addition of platinum salts to neoadjuvant chemotherapy in triple-negative breast cancer: a new standard of care? Lancet Oncol. 2018 Apr;19(4):434-6. doi: 10.1016/ S1470-2045(18)30129-3.

29. Masuda N, Lee S-J, Ohtani S, Im Y-H, Lee E-S, Yokota I. Adjuvant capecitabine for breast cancer after preoperative chemotherapy. N Engl J Med. 2017;376:2147-59. doi: 10.1056/ NEJMoa1612645.

30. Papadimitriou M, Mountzios G, Papadimitriou CA. The role of PARP inhibition in triple-negative breast cancer: unraveling the wide spectrum of synthetic lethality. Cancer Treat Rev. 2018 Jun;67:34-44. doi: 10.1016/j.ctrv.2018.04.010.

31. Wahba HA, El-Hadaad HA. Current approaches in treatment of triple-negative breast cancer. Cancer Biol Med. 2015 Jun; 12(2):106-16. doi: 10.7497/j.issn.2095-3941.2015.0030. 
32. Jerusalem G, Collignon J, Schroeder H, Lousberg L. Triplenegative breast cancer: treatment challenges and solutions. Breast Cancer Targets Ther. 2016 May 20;8:93-107. doi: 10.2147/BCTT.S69488.

33. Robson M, Im S-A, Senkus E, Xu B, Domchek SM, Masuda $\mathrm{N}$. Olaparib for metastatic breast cancer in patients with a germline BRCA mutation. N Engl J Med. 2017;377:523-33. doi: 10.1056/NEJMoa1706450.

34. Mina A, Yoder R, Sharma P. Targeting the androgen receptor in triple-negative breast cancer: current perspectives. Onco Targets Ther. 2017 Sep 20;10:4675-85. doi: 10.2147/OTT. S126051.

35. Schmid P, Adams S, Rugo HS, Schneeweiss A, Barrios CH, Iwata $\mathrm{H}$. Atezolizumab and Nab-paclitaxel in advanced triplenegative breast cancer. N Engl J Med. 2018 Nov 29;379 (22):2108-21. doi: 10.1056/NEJMoa1809615.

36. Schmid P, Cortes Castan J, Bergh J, Pusztai L, Denkert C, Verma S. KEYNOTE-522: Phase III study of pembrolizumab (pembro) + chemotherapy (chemo) vs placebo + chemo as neoadjuvant followed by pembro vs placebo as adjuvant therapy for triple-negative breast cancer (TNBC). Ann Oncol. 2017;28 (Suppl 5):v68-v73. doi:10.1093/annonc/mdx364

37. World Medical Association. World Medical Association Declaration of Helsinki: ethical principles for medical research involving human subjects. JAMA. 2013 Nov 27;310(20):2191-4. doi:10.1001/jama.2013.281053.

38. Hammond MEH, Hayes DF, Dowsett M, Allred DC, Hagerty KL, Badve S, et al. American Society of Clinical Oncology/ College of American Pathologists guideline recommendations for immunohistochemical testing of estrogen and progesterone receptors in breast cancer. Arch Pathol Lab Med. 2010 Jun;134(6):907-22. doi: 10.1043/1543-2165-134.7.e48.

39. Wolff AC, Hammond MEH, Allison KH, Harvey BE, Mangu $\mathrm{PB}$, Bartlett JMS, et al. Human epidermal growth factor receptor 2 testing in breast cancer: American Society of Clinical Oncology/College of American Pathologists Clinical Practice Guideline Focused Update. J Clin Oncol. 2018 Jul 10;36 (20):2105-22. doi: 10.1200/JCO.2018.77.8738.

40. Ovcaricek T, Grazio Frkovic S, Matos E, Mozina B, Borstnar S. Triple negative breast cancer - prognostic factors and survival. Radiol Oncol. 2011;45(1):46-52. doi:10.2478/v10019-0100054-4.

41. Pistelli M, Pagliacci A, Battelli N, Santinelli A, Biscotti T, Ballatore $Z$, et al. Prognostic factors in early-stage triple-negative breast cancer: lessons and limits from clinical practice. Anticancer Res. 2013;33:2737-42.

42. Urru SAM, Gallus S, Bosetti C, Moi T, Medda R, Sollai E, et al. Clinical and pathological factors influencing survival in a large cohort of triple-negative breast cancer patients. BMC Cancer. 2018;18:56. doi: 10.1186/s12885-017-3969-y.

43. Chintalapani SR, Bala S, Konatam ML, Gundeti S, Kuruva SP, Hui M. Triple-negative breast cancer: pattern of recurrence and survival outcomes. Indian J Med Paediatr Oncol. 2019;40:6772. doi: 10.4103/ijmpo.ijmpo_132_18.

44. Fayaz S, Demian GA, El-Sherify M, Eissa H, Aziz M, Abuzallouf S. Triple negative breast cancer: 10 -year survival update of the applied treatment strategy in Kuwait. Gulf J Oncol. 2019 Jan 1;29:53-9. doi: 10.1016/j.rpor.2013.08.007.

45. Akdeniz A, Yalcin S, Rahatli S, Kucukoztas N, Yagmurdur MC, Dizdar O, et al. Clinical and pathological characteristics of triple negative breast cancer patients: a single-center experience. JCO. 2012;30(15 Suppl):e11515. doi: 10.1200/jco.2012.30.15_ suppl.e11515.

46. Paluch-Shimon S, Cardoso F, Sessa C, Balmana J, Cardoso MJ, Gilbert $\mathrm{F}$, et al. Prevention and screening in BRCA mutation carriers and other breast/ovarian hereditary cancer syndromes: ESMO Clinical Practice Guidelines for cancer prevention and screening. Ann Oncol. 2016 Sep;27(Suppl 5):v103-10. doi: 10.1093/annonc/mdw327.

47. Qiu J, Xue X, Hu C, Xu H, Kou D, Li R, et al. Comparison of clinicopathological features and prognosis in triple-negative and non-triple negative breast cancer. J Cancer. 2016;7(2):16773. doi:10.7150/jca.10944.

48. Chen T, Zhang N, Moran MS, SU P, Haffty BG, Yang Q. Borderline ER-positive primary breast cancer gains no significant survival benefit from endocrine therapy: a systematic review and meta-analysis. Clin Breast Cancer. 2018 Feb;18(1):1-8. doi: 10.1016/j.clbc.2017.06.005.

49. Plasilova ML, Hayse B, Killelea BK, Horowitz NR, Chagpar $\mathrm{AB}$, Lannin DR. Features of triple-negative breast cancer. Analysis of 38,813 cases from the national cancer database. Medicine. 2016;95:35 (e4614). doi: 10.1097/MD.00000000 00004614.

50. Foulkes WD, Grainge MJ, Rakha EA, Green AR, Ellis IO. Tumor size is an unreliable predictor of prognosis in basal-like breast cancers and does not correlate closely with lymph node status. Breast Cancer Res Treat. 2009;117:199-204. doi: 10.1007/s10549-008-0102-6.

51. Lin NU, Vanderplas A, Hughes ME, Theriault RL, Edge SB, Wong YN, et al. Clinicopathological features, patterns of recurrence, and survival among women with triple-negative breast cancer in the National Comprehensive Cancer Network. Cancer. 2012 Nov 15;118(22):5463-72. doi: 10.1002/cncr. 27581.

52. Giuliano AE, Edge SB, Hortobagyi GN. Eighth Edition of the AJCC Cancer Staging Manual: Breast Cancer. Ann Surg Oncol. 2018 Jul 18;25(7):1783-5. doi: 10.1245/s10434-018-6486-6.

53. Cardoso F, Kyriakides S, Ohno S, Penault-Llorca F, Poortmans P, Rubio IT, et al. Early breast cancer: ESMO Clinical Practice Guidelines for diagnosis, treatment and follow-up. Ann Oncol. 2019;30:1194-220. doi: 10.1093/annonc/mdz173.

54. Curigliano G, Burstein HJ, Winer EP, Gnant M, Dubsky P, Loibl S, et al. De-escalating and escalating treatments for earlystage breast cancer: the St. Gallen International Expert Consensus Conference on the Primary Therapy of Early Breast Cancer 2017. Ann Oncol. 2017 Aug 1;28(8):1700-12. doi: 10.1093/annonc/mdx308.

55. Bundred NJ. Prognostic and predictive factors in breast cancer. Cancer Treat Rev. 2001 Jun;27(3):137-42. doi: 10.1053/ctrv. 2000.0207.

56. Cianfrocca M. Prognostic and predictive factors in early-stage breast cancer. Oncologist. 2004 Nov 1;9(6):606-16. doi: 10.1634/theoncologist.9-6-606. 


\title{
Sažetak
}

\section{KARAKTERISTIKE I PROGNOZA BOLESNICA S TROSTRUKO NEGATIVNIM RAKOM DOJKE: HRVATSKA MONOINSTITUCIJSKA RETROSPEKTIVNA KOHORTNA STUDIJA}

\author{
A. Tečić Vuger, R. Šeparovic, Lj. Vazdar, M. Pavlović, P. Lepetic, S. Šitić, Ž. Bajić, B. Šarčević i D. Vrbanec
}

Trostruko negativni rak dojke (TNRD) javlja se u oko šestine svih bolesnica s rakom dojke, s najagresivnijim ponašanjem i najgorom prognozom od svih podtipova raka dojke. To je heterogena bolest sa specifičnim molekularnim karakteristikama i prirodnom dinamikom ranog povrata i brze progresije bolesti. Zbog nedostatka biobiljega ili bilo kakvog uporabljivog terapijskog cilja temelj liječenja i dalje je klasična citotoksična kemoterapija. Analizirali smo kohortu od 152 bolesnice, medijan dobi 58 godina, dijagnosticirane i liječene od ranog TNRD u Klinici za tumore Kliničkoga bolničkog centra Sestre milosrdnice u Zagrebu, Hrvatska u razdoblju od 2009. do 2012. godine. Bolesnice su liječene primarno kirurškim pristupom, adjuvantnom kemoterapijom i adjuvantnim zračenjem. Zamijetili smo relativno velik udio lokalno uznapredovalog stadija TNRD pri dijagnozi, s velikom veličinom tumora i zahvaćanjem limfnih čvorova, visokim gradusom i visokim proliferacijskim indeksom Ki 67. Dob bolesnica, veličina tumora i zahvaćenost limfnih čvorova, očekivano, pokazali su se statistički značajnim i klinički najvažnijim prognostičkim čimbenicima petogodišnjeg preživljenja bez bolesti (67\%; 95\% CI 60-75\%) i stope sveukupnog preživljenja (74\%; 95\% CI 66-81\%).

Ključne riječi: Trostruko negativni rak dojke; Rani rak; Adjuvantno liječenje; Veličina tumora; Limfni čvor; Preživljenje bez bolesti; Sveukupno preživljenje; Prognostički čimbenik 